\title{
The effectiveness of intravaginal progesterone insert in Ovsynch and resynchronization protocols in cyclic and non-cyclic Holstein heifers
}

\author{
Murat ABAY ${ }^{1, a, ®}$, Örsan GÜNGÖR ${ }^{2, b}$, Şükrü Metin PANCARCI ${ }^{3, c}$, Tayfur BEKYÜREK ${ }^{1, d}$, \\ Mehmet KAYA $^{4, \mathrm{e}}$, Ömer Orkun DEMİRAL ${ }^{5, \mathrm{f}}$, Kutlay GÜRBULAK ${ }^{1, \mathrm{~g}}$, Esra CANOOĞLU ${ }^{1, \mathrm{~h}}$, \\ Mustafa ÜN $\mathbf{N}^{6, \mathrm{i}}$
}

\begin{abstract}
${ }^{1}$ Erciyes University, Faculty of Veterinary Medicine, Department of Obstetrics Gynecology and Reproduction, Kayseri; ${ }^{2}$ Mehmet Akif Ersoy University, Faculty of Veterinary Medicine, Department of Obstetrics Gynecology and Reproduction, Burdur; ${ }^{3}$ Balıkesir University, Faculty of Veterinary Medicine, Department of Obstetrics Gynecology and Reproduction, Balıkesir; ${ }^{4}$ Ondokuz Mayıs University, Faculty of Veterinary Medicine, Department of Physiology, Samsun; ${ }^{5}$ Erciyes University, Faculty of Veterinary Medicine, Department of Reproduction and Artificial Insemination, Kayseri, ${ }^{6}$ Adalar Municipality, Istanbul, Turkey. aORCID: 0000-0003-2457-1919; ' ${ }^{\mathrm{O} O R C I D: ~ 0000-0002-4576-9740 ; ~ ' ~}{ }^{\circ}$ ORCID: 0000-0002-7235-2502;

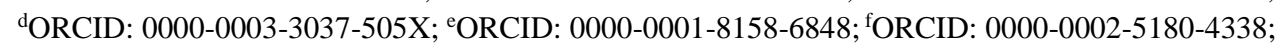
gORCID: 0000-0002-1176-9881; hORCID: 0000-0002-7881-9484; i ORCID: 0000-0001-8888-2308
\end{abstract}

Corresponding author: mabay@erciyes.edu.tr

Received date: 09.06.2020- Accepted date: 13.09.2020

\begin{abstract}
In the present study, it was aimed to compare of resynchronization with used progesterone (P4) releasing intravaginal device (PRID), with modified ovulation synchronization in cyclic and non-cyclic Holstein heifers. Animals were randomly divided into two groups; Group I (GI, n=87) and Group II (GII, n=88). Fixed-time artificial insemination (FTAI) following modified Ovsynch protocol with PRID insertion, was performed to all animals. In GI, used PRID was reinserted to the same animals, 15 days after the first FTAI (day 25) for 12 days. Pregnancies were detected by ultrasound in all groups on day 37. For resynchronization, prostaglandin (PG) $F_{2} \alpha$ was applied to non-pregnant animals on day 37. In GI, following 48 hours from PGF $_{2} \alpha$ injection, the gonadotropin-releasing hormone was administrated, and after 18 hours the second FTAI was performed. No additional treatments were applied to the nonpregnant animals found in GII, and heifers were taken to the routine service program. In both groups, the second pregnancy diagnosis was performed 27 days after inseminations by transrectal ultrasonography. Pregnancy rates (PR) following the first and overall inseminations in cyclic and non-cyclic heifers (GI and GII) were detected as 66.4\% and 52.3\% (P>0.05); 76.3\% and 59.1\% (P>0.05), respectively. In conclusion, the usage of PRID in the Ovsynch and resynchronization protocol resulted in higher PRs of non-cyclic heifers than cyclic heifers. Moreover, this study reveals that the initial P4 levels of non-cyclic animals should be used as a determinant for pregnancy success in dairy heifers.
\end{abstract}

Keywords: Heifer, pregnancy, progesterone, resynchronization.

\section{Siklik ve siklik olmayan Holştayn düvelerde Ovsynch ve resenkronizasyon protokollerinde intravajinal progesteron ilavesinin etkinliği}

Özet: Sunulan çalışmada, siklik ve siklik olmayan Holştayn ırkı düvelerde modifiye ovulasyon senkronizasyonu ve kullanılmış progesteron (P4) salan intravajinal araç (PRID) ile resenkronizasyonun etkinliğinin karşılaştırılması amaçlandı. Hayvanlar rastgele iki gruba ayrıld1; Grup I (GI, n = 87) ve Grup II (G II, n= 88). Tüm hayvanlara PRID eklenerek modifiye edilmiş bir Ovsynch protokolünü takiben sabit zamanlı suni tohumlama (SZT) yapıldı. Grup I'de, kullanılmış PRID, ilk SZT'dan 15 gün sonra (25. gün) 12 gün süreyle aynı hayvanlara tekrar yerleştirildi. Tüm gruplarda 37. günde ultrason ile gebelikler saptandı. Resenkronizasyon için, gebe olmayan hayvanlara 37. günde prostaglandin (PG) $\mathrm{F}_{2} \alpha$ uyguland1. Grup I'de $\mathrm{PGF}_{2} \alpha$ enjeksiyonundan 48 saat sonra gonadotropin salg1latıc1 hormon uygulandı ve 18 saat sonra ikinci SZT yapıldı. Grup II' deki gebe olmayan hayvanlara ilave tedavi uygulanmadı ve düveler rutin tohumlama programına alındı. Her iki grupta da ikinci gebelik teşhisi SZT'dan 27 gün sonra transrektal ultrasonografi ile yapıldı. Siklik ve siklik olmayan düvelerdeki (GI ve GII) ilk ve tüm tohumlamaları takiben gebelik oranları sırasılla \%66,4 ve \%52,3 (P>0,05); \%76,3 ve \%59,1 (P>0,05) olarak saptandı. Sonuç olarak, Ovsynch ve resenkronizasyon protokolünde PRID kullanımı, siklik olmayan düvelerin siklik olan düvelerden daha yüksek gebelik oranları ile sonuçlandı. Ayrıca, bu çalışma, siklik olmayan hayvanların başlangıçtaki P4 düzeylerinin, sütçü düvelerde gebelik başarısı için belirleyici olarak kullanılması gerektiğini ortaya koymaktadır.

Anahtar sözcükler: Düve, gebelik, progesteron, resenkronizasyon. 


\section{Introduction}

Reproductive efficiency is one of the main determinants of economic benefit in dairy herds (24). It is reported that decrease in pregnancy rates (PR) heifers due to poor estrus behaviours, lower conception rates and high embryonic deaths (30). In addition, the time interval for pregnancy is getting longer because of inadequate managements in crowded herds and inefficient estrus detection $(3,6,7)$. Various programs have been used for estrus synchronization in dairy cow and heifers $(8,18,30)$. Thereby, estruses could be detected effectively and time spend for heat detection could be decreased in cows and heifers $(18,27,31)$. Pharmacological control of estrus cycle to increase pregnancy rates has been achieved through synchronization of follicular development, control of corpus luteum regression and synchronization of ovulation $(1,15,19,20,27,28)$.

In current synchronization programs, no application has been considered for non-pregnant animals after insemination $(2,6,24)$. Therefore, economical income obtained from non-pregnant animals is decreased. To overcome this issue, the resynchronization programs have been developed for recent years $(2,8,13)$. Synchronization programs used for animals that are diagnosed as non-pregnant following the first insemination have been named as resynchronization programs (3) and various protocols were developed for resynchronization (6).

In resynchronization programs, it is aimed to initiate the subsequent cycle, regardless of whether animals become pregnant in the previous insemination (22). In the case of pregnancy, resynchronization is ceased. Otherwise, resynchronization processing is continued. Resynchronization protocols mainly include the use of progesterone (P4) and this hormone does not harm an ongoing pregnancy $(14,16)$. Indeed, $\mathrm{P} 4$ administration for resynchronization prevents embryonic deaths (10).

Nowadays, pregnancy rates following resynchronization protocols were insufficient in heifers. The objective of this study is to investigate the efficacy of the resynchronization program with the use of $\mathrm{P} 4$ based on pregnancy rates especially in dairy heifers. In synchronization protocols with the use of $\mathrm{P} 4, \mathrm{P} 4$ devices are discarded following synchronization. However, it has been demonstrated that PRID releases for at least 15 days which is longer than its usage in the vagina (10). Therefore, the second objective of this study is to investigate the effectiveness of the re-use of PRID for resynchronization process to increase PRs to the decrease cost of resynchronization, in heifer.

\section{Materials and Methods}

Animals: This study was carried out on healthy Holstein heifers ( $\mathrm{n}=180)$ older than 15 months of age, and the body condition scores (12) all of the animals used were close to each other. All animals were fed and managed under the same conditions at the the Günta Agriculture and Livestock Inc. Kayseri, Turkey. Heifers were fed with alfalfa hay, corn silage and concentrated feed, accessed to water ad libitum basis in free-stall barns, throughout the study. All procedures on animals were carried out according to approval by the Local Ethics Committee for Animal Experiments of Erciyes Veterinary Medicine Faculty with the number of 2006/040 during this study.

Animals were randomly allocated to Group I (GI, Resynchronization; $\mathrm{n}=90$ ) and Group II (GII, Control; $\mathrm{n}=90$ ), respectively. The occurrence of oestrous cycles (cyclic vs. non-cyclic) before the onset of treatments was determined by measuring the $\mathrm{P} 4$ serum concentration level in the blood samples collected on day-10 and day 0 . The detecting of serum P4 level as $<1 \mathrm{ng} / \mathrm{ml}$ in all animals at the days mentioned above was evaluated non-cyclic status. In addition, blood samples were collected from all heifers on day +7 and +10 to detect $\mathrm{P} 4$ concentration. All sera samples were stored at $-20^{\circ} \mathrm{C}$ until measurements.

During the experimental period, three heifers in GI and two heifers in GII were excluded from the study due to the loss of their PRID.

Reproductive Management: In GI $(n=87)$ and GII $(\mathrm{n}=88)$, intravaginal device (PRID; $1.55 \mathrm{~g}$ progesterone + $10 \mathrm{mg}$ estradiol benzoate, CEVA-DIF, Turkey) was inserted at the time of the GnRH (Ovarelin; $50 \mu \mathrm{g} / \mathrm{mL}$ gonadoreline diacetate, CEVA-DIF, Turkey, $2 \mathrm{~mL}$, IM) injection (day 0). $\mathrm{PGF}_{2} \alpha$ (Estrumate; $250 \mu \mathrm{g} / \mathrm{mL}$ cloprostenol, CEVA-DIF, Turkey, $2 \mathrm{~mL}$, IM) was administered on the day of PRID removal (day 7) and the second GnRH was injected 48 hours later (day 9). FTAI was performed to all animals, 18 hours after the second GnRH administration (day 10).

PRIDs removed from heifers in GI at day 7 were cleaned and disinfected with $0.1 \%$ chlorhexidine solution and kept individually in a refrigerator until they were reused for resynchronization. Used PRIDs without estradiol capsule were reinserted to the same animals 15 days after the FTAI (day 25) and held during 12 days.

On day 37, pregnancies were detected by transrectal ultrasonography (Honda HS 1500V, Japan) equipped with a rectal linear probe $(5 \mathrm{MHz})$, in all groups.

In GI, $\mathrm{PGF}_{2} \alpha$ was applied to non-pregnant animals on day 37. The GnRH was administered 48 hours after $\mathrm{PGF}_{2} \alpha$ injection (day 39), and the second FTAI was performed 18 hours following GnRH injection (day 40). No additional treatments were applied to the non-pregnant animals found in GII and heifers were taken to the routine service program. In GII, heat patches KAMAR (Rumitech, USA) attached to tail head were used to detect estrus. Heifers detected estrus in GII were inseminated after 12 hours following estrus detection. 
In both groups, the second pregnancy diagnosis was performed 27 days after inseminations by transrectal ultrasonography.

Hormone Assays: The blood P4 levels were determined by ELISA described as previously (23). For sera $\mathrm{P} 4$ analyses, intra-experimental and inter-experiment variation coefficients were 0.09 and 0.14 for low control and 0.11 and 0.17 for high control, respectively.

Statistical Analysis: Pregnancy rates and rate of non-cycling heifers between groups were analysed with the Chi-square test. The significance control of the differences in P4 levels between cyclic and non-cyclic heifers in GI and GII was performed using the Student Ttest. The statistical significance control of the change in the PR in the first insemination according to the total PR was done with the Mantel-Haenszel test. NCSS 9.0 package program was performed in all statistical analyses.

\section{Results}

The rate of non-cycling heifers was numerically lower in GI $(20.7 \%$; 18/87) compared to that in GII $(29.5 \% ; 26 / 88)(\mathrm{P}>0.05)$.
Pregnancy rates following the first insemination did not differ between GI $(60.9 \%$; 53/87) and II $(64.8 ; 57 / 88)$ ( $\mathrm{P}>0.05)$. The pregnancy rates in GI after the second FTAI were detected as $38.2 \%$ (13/34). Only four of 31 heifers were inseminated after the detection of estrus in GII. Three of four animals inseminated were diagnosed as pregnant $(9.68 \% ; 3 / 31)$. Pregnancy rates following the first and second inseminations (overall pregnancy rate) did not differ between GI $(75.9 \%$; 66/87) and GII $(68.2 \%$; 60/88) $(\mathrm{P}>0.05)$. Although the increase of between first and overall PRs were significant in GI $(\mathrm{P}=0.034)$; no significant result was detected in GII $(\mathrm{P}=0.634)$; (Figure $1)$.

The pregnancy rates of cyclic and non-cyclic animals in GI and GII were given in detail in Table 1. In non-cyclic heifers of GI and GII, the blood P4 levels at day -10 and day 0 were detected as $0.21 \pm 0.13 ; 0.35 \pm 0.26 \mathrm{ng} / \mathrm{mL}$ $(\mathrm{P}=0.038)$ and $0.18 \pm 0.19 ; 0.37 \pm 0.28 \mathrm{ng} / \mathrm{mL}(\mathrm{P}=0.017)$, respectively. Progesterone concentrations of cyclic and non-cyclic animals in GI and GII at day $-10,0,+7$ and +10 were summarized in Figure 2.

\section{口First Service $\quad$ Overall Service}

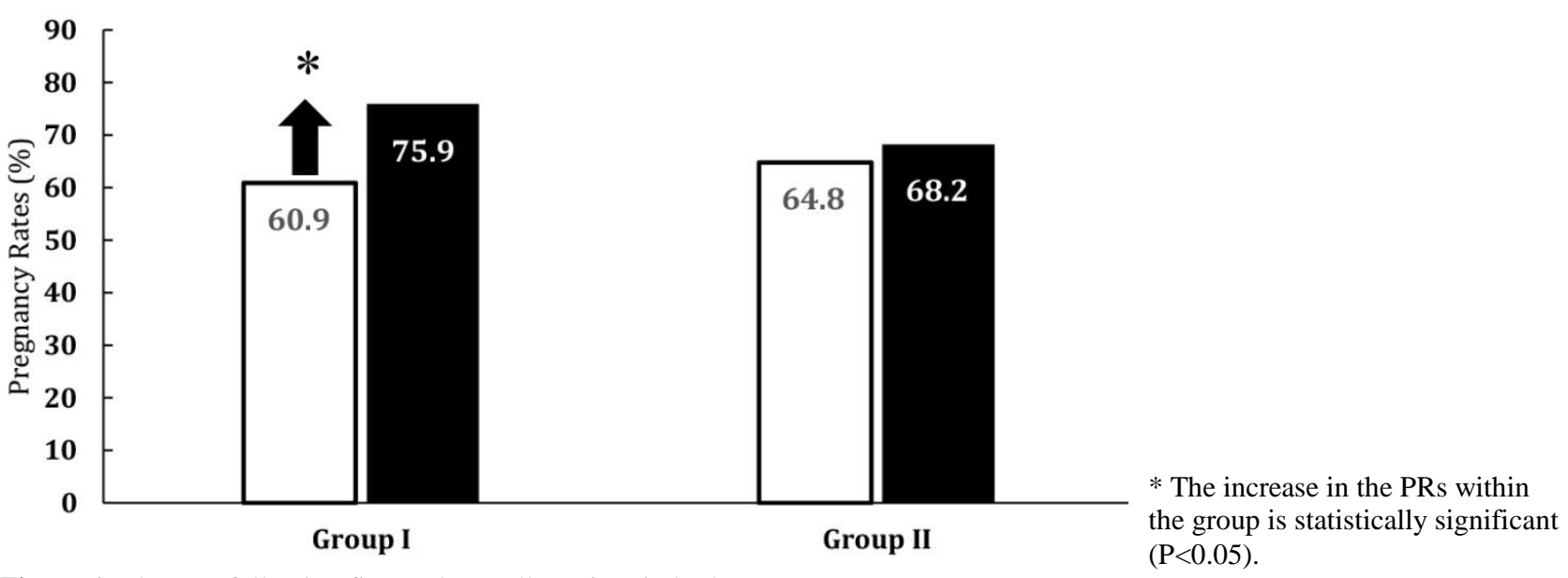

Figure 1. The PRs following first and overall services in both groups.

Table 1. The PRs after first and overall inseminations of cyclic and non-cyclic dairy heifers in and between GI and GII.

\begin{tabular}{|c|c|c|c|c|c|c|}
\hline & & \multicolumn{2}{|c|}{ Non-Cyclic } & \multicolumn{2}{|c|}{ Cyclic } & \multirow[b]{2}{*}{$\begin{array}{c}P \\
\text { Value for Cyclicity }\end{array}$} \\
\hline & Groups & $\begin{array}{c}\text { Pregnant } \\
\text { n }(\%)\end{array}$ & $\begin{array}{c}\text { Non-pregnant } \\
\text { n }(\%)\end{array}$ & $\begin{array}{c}\text { Pregnant } \\
\text { n }(\%)\end{array}$ & $\begin{array}{c}\text { Non-pregnant } \\
\text { n }(\%)\end{array}$ & \\
\hline \multirow{3}{*}{$\begin{array}{c}\text { First } \\
\text { Insemination }\end{array}$} & GI & $7(38.9)$ & $11(61.1)$ & $46(66.7)$ & $23(33.3)$ & 0.060 \\
\hline & GII & $16(61.5)$ & $10(38.5)$ & $41(66.1)$ & $21(33.9)$ & 0.868 \\
\hline & $\begin{array}{c}\mathrm{P} \\
\text { Values for } \\
\text { Groups }\end{array}$ & \multicolumn{2}{|c|}{0.241} & \multicolumn{2}{|c|}{0.948} & \\
\hline \multirow{3}{*}{$\begin{array}{c}\text { Overall } \\
\text { Insemination }\end{array}$} & GI & $9(50.0)$ & $9(50.0)$ & 57 (82.6) & $12(17.4)$ & 0.010 \\
\hline & GII & $17(65.4)$ & 9 (34.6) & $43(69.4)$ & 19 (30.6) & 0.909 \\
\hline & $\begin{array}{c}\mathrm{P} \\
\text { Values for } \\
\text { Groups }\end{array}$ & \multicolumn{2}{|c|}{0.479} & \multicolumn{2}{|c|}{0.115} & \\
\hline
\end{tabular}




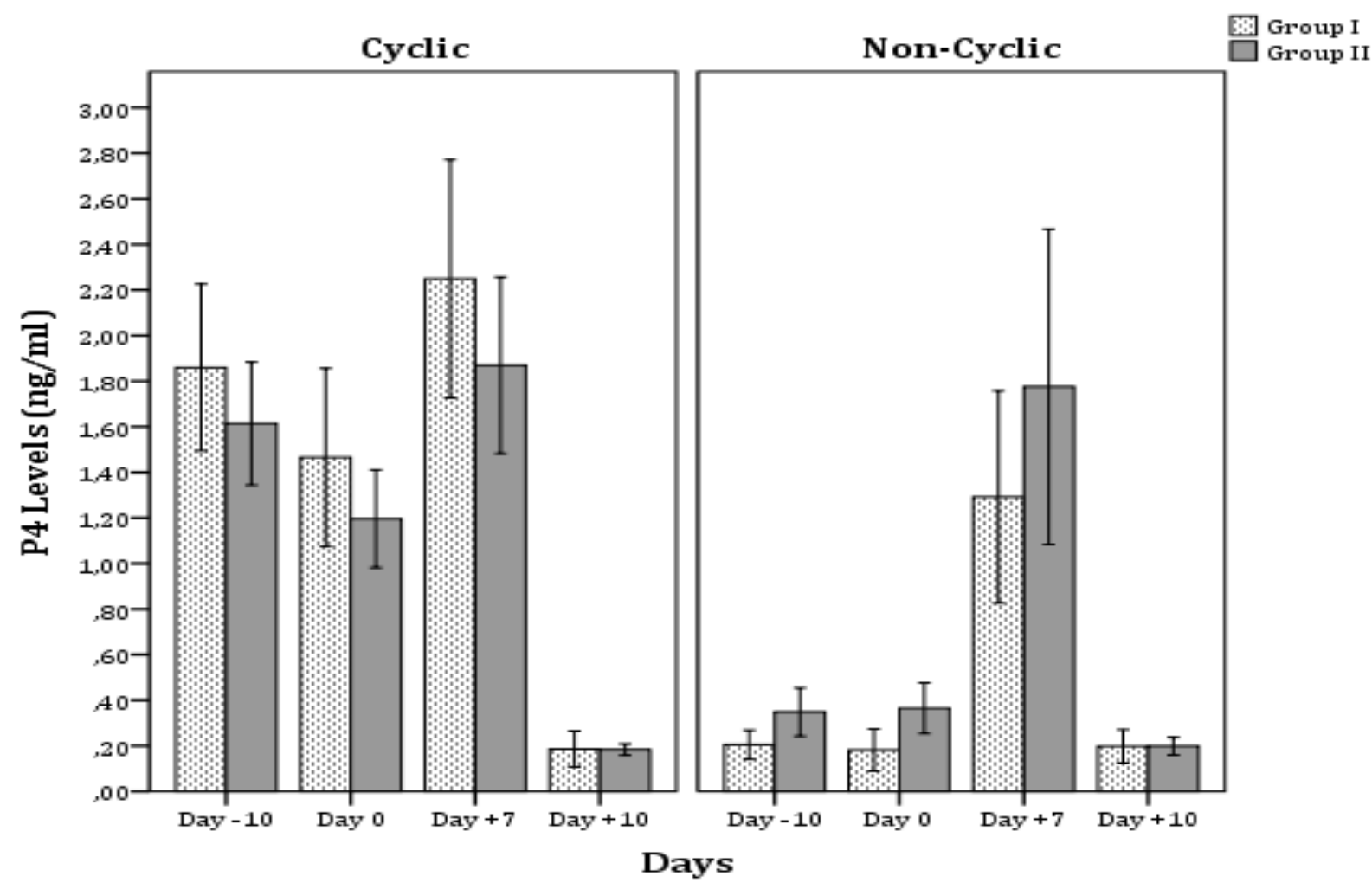

In cyclic dairy heifers, no statistical difference between serum $\mathrm{P} 4$ levels in all days $(\mathrm{P}>0.05)$.

* In non-cyclic dairy heifers, the statistical difference between serum $\mathrm{P} 4$ levels at days $-10(\mathrm{P}=0.021)$ and $0(\mathrm{P}=0.017)$ is significant.

Figure 2. The mean serum P4 levels (ng/mL) of cyclic and non-cyclic dairy heifers in GI and GII at days $-10,0,+7$ and +10 .

\section{Discussion and Conclusion}

The effect of cyclicity of beef and dairy heifers on the success of PRs obtained after modified ovulation synchronization (OVS) protocols have been recently questioned by some researchers (17). In accordance with the results of Lopez Helguera et al. (17), we found that the cyclicity of the dairy heifers also affects the success in modified synchronization protocols numerically.

While the average PRs of non-cyclic and cyclic animals were found as $53.27 \%$ and $66.41 \%$ following to first FTAI $(\mathrm{P}>0.05)$, the overall PRs were increased to $59.09 \%$ and $76.34 \%$, respectively at the end of our study $(\mathrm{P}>0.05)$. The PRs obtained after the first FTAI with OVS (with P4 insertion) indicate that non-cyclic animals decrease the PRs in dairy heifers. Also, the overall PRs detected in GI indicate that the resynchronization of the heifers with used PRID after OVS increases the PRs in both non-cyclic and cyclic animals. As the results reported in a previous study (29), the overall PRs obtained from GI and GII presented that the application of the resynchronization protocol let us have an economically acceptable value than routine service programs in our study. This result also revealed that resynchronization using P4 is an effective method to increase PRs in noncyclic animals.
In non-cyclic heifers, it's also so interesting that while the blood P4 levels of GI at day -10 and 0 were detected lower than those of GII $(\mathrm{P}<0.05)$, the PRs of GII were higher than that of GI $(P>0.05)$. Considering these results together, in non-cyclic animals, even if the $\mathrm{P} 4$ levels were below $1 \mathrm{ng} / \mathrm{mL}$ at the beginning of OVS affect the PRs. The data obtained in this study were considered to be compatible with the studies conducted previously (4, 5) in which it was reported that the level of P4 was important before and during synchronization applications in terms of follicular development, ovulation, and embryonic development in cows. Since the number of relevant literature is limited in dairy heifers compared with dairy cows, therefore it is thought that the results of the current study were important.

Moreover, it's obvious that the numerical differences of PRs between GI and GII could be interpreted in consequence of the $\mathrm{P} 4$ administration in resynchronization protocol. Also, the overall PRs obtained in the study reveal that the negative effect of heifers' cyclicity at the beginning of the study could be decreased to an acceptable level by resynchronization with $\mathrm{P} 4$. The results that reported by Stevenson et al. (29) go along with our results.

The PRID is generally used once in animals and the duration of use varies between 5 and 12 days in field 
conditions. However, it has been reported that short term used PRIDs could be re-used $(11,33)$. Our study showed that re-using of the PRIDs for 19 days was found to be successful in PRs obtained. In addition to all these, it was demonstrated that the resynchronization protocol used had advantages such as inseminating 2 times in a short period of 40 days in heifers.

Moreover, the expression of estrus in some nonpregnant heifers following the Ovsynch protocol integrated with $\mathrm{P} 4$ administration in this study could be due to the induction of cyclicity in those heifers previously non-cycling. Similar findings were reported by Chebel et al. (7).

Pregnancy rates obtained following the first insemination in this study were slightly higher than the results of previous reports in dairy $(58.7 \%$; (28)) and beef (44.1\%; (20)) heifers following the Ovsynch protocol with $\mathrm{P} 4$ administration. It has been reported that PRs could be differ due to the cyclicity status of animals and the stage of the estrous cycle at the beginning of the synchronization protocols $(26,28)$. The present study revealed that serum $\mathrm{P} 4$ levels in non-cyclic heifers at the beginning of the study also affected PRs. This slightly higher PR in the current study could be attributed to a lower rate of noncyclic heifers than the previously reported rate of anestrus $(20-40 \%)$ in dairy cows at the beginning of synchronization protocols (21). Although P/AI for the second service in GI was lower than GII, PR to the second service was higher in GI compared to GII. This discordance between P/AI and PRs was basically due to the higher submission rate in GI.

Colazo et al. (9), reported that a once or twice-used CIDR for resynchronization resulted in the majority of non-pregnant heifers detected in estrus over a 4-day interval, with acceptable conception rates. In this regard, 78.5\% PR following resynchronization has been reported, and twice-used CIDR for resynchronization resulted in 7080\% PRs in beef heifers. In this study, similar PR (75.9\%) was obtained following resynchronization in dairy heifers. Colazo et al. (11) reported $54.1 \%$ PR following resynchronization with a used intravaginal progesteronereleasing insert in beef heifers. In the current study, the PR (75.9\%) was higher than that $(54.1 \%)$ reported by Colazo et al. (11) in beef heifers. Differences in PRs reported in the studies could be attributed to the synchronization protocol, type of rearing, and the breed of the animals. As a matter of fact, in our study, P4-supported OVS was used in dairy heifers. However, Rivera et al. (25) reported that PR was detected $79 \%$ following resynchronization with intravaginal progesterone releasing insert after AI in Holstein heifers. Similarly, we found that PRs were diagnosed as $75.9 \%$.

It has been reported that PRs for resynchronization could be lower following the insertion of PRID after the first service compared to the first service PRs due probably to the development of persistent dominant follicles during P4 insertion $(6,10,32)$. A lower PR obtained following resynchronization $(38.2 \%)$ compared to the first service $(60.9 \%)$ in this study could be attributed to the development of the persistent dominant follicle.

In conclusion, first of all, it was detected that PRs in dairy heifers can be increased by resynchronization applications with P4. As a secondary result, it was determined that PRID effectiveness continues up to 19 days in the resynchronization protocols. The most important of all, it was revealed that P4 levels had a significant effect on PRs before ovulation synchronization in non-cyclic dairy heifers. Therefore, further investigations regarding the level and effectiveness of P4 in terms of follicular development.

\section{Financial Support}

This study was financially supported by the TÜBİTAK (The Scientific and Technological Research Council of Turkey)-Agriculture, Forestry and Veterinary Sciences Research Grant Group-Turkey (Project No. TOVAG-107O177).

\section{Ethical Statement}

This study was approved by the Local Ethics Committee for Animal Experiments of Erciyes Veterinary Medicine Faculty (2006/040).

\section{Conflict of Interest}

The authors declared that there is no conflict of interest.

\section{References}

1. Ambrose JD, Kastelic JP, Rajamahendran R, et al (2005): Progesterone (CIDR)-based timed AI protocols using GnRH, porcine LH or estradiol cypionate for dairy heifers: ovarian and endocrine responses and pregnancy rates. Theriogenology, 64, 1457-1474.

2. Bartolome JA, Sozzi A, McHale J, et al (2005): Resynchronization of ovulation and timed insemination in lactating dairy cows, I: use of the Ovsynch and Heatsynch protocols after non-pregnancy diagnosis by ultrasonography. Theriogenology, 63, 1617-1627.

3. Bartolome JA, Sozzi A, McHale J, et al (2005): Resynchronization of ovulation and timed insemination in lactating dairy cows, II: assigning protocols according to stages of the estrous cycle, or presence of ovarian cysts or anestrus. Theriogenology, 63, 1628-1642.

4. Bisinotto RS, Castro LO, Pansani MB et al (2015): Progesterone supplementation to lactating dairy cows without a corpus luteum at initiation of the Ovsynch protocol. J Dairy Sci, 98, 2515-2528.

5. Cavalieri J (2018): Absence of a corpus luteum and relatively lesser concentrations of progesterone during the period of pre-ovulatory follicle emergence results in lesser 
pregnancy rates in Bos indicus cattle. Anim Reprod Sci, 204, 39-49.

6. Cavalieri J, Hepworth G, Fitzpatrick LA, et al (2006): Manipulation and control of the estrous cycle in pasturebased dairy cows. Theriogenology, 65, 45-64.

7. Chebel RC, Santos JEP, Cerri RLA, et al (2006): Reproduction in dairy cows following progesterone insert presynchronization and resynchronization protocols. J Dairy Sci, 89, 4205-4219.

8. Çolak A, Bekyürek T, Öztürkler Y (1995): Ineklerde postpartum dönemde $P G F_{2} \alpha$ ile östrus sinkronizasyonu çalışmaları. Kafkas Üniv Vet Fak Derg, 1, 22-24.

9. Colazo MG, Kastelic JP, Mainar-Jaime RC et al (2006): Resynchronization of previously timed-inseminated beef heifers with progestins. Theriogenology, 65, 557-572.

10. Colazo MG, Kastelic JP, Small JA et al (2007): Resynchronization of estrus in beef cattle: ovarian function, estrus and fertility following progestin treatment and treatments to synchronize ovarian follicular development and estrus. Can Vet J, 48, 49-56.

11. Colazo MG, Kastelic JP, Whittaker PR et al (2004): Fertility in beef cattle given a new or previously used CIDR insert and estradiol, with or without progesterone. Anim Reprod Sci, 81, 25-34.

12. Edmonson AJ, Lean IJ, Weaver LD et al (1989): A body condition scoring chart for Holstein dairy cows. J Dairy Sci, 72, 68-78.

13. Fricke PM, Caraviello DZ, Weigel KA et al (2003): Fertility of dairy cows after resynchronization of ovulation at three intervals following first timed insemination. J Dairy Sci, 86, 3941-3950.

14. Galvano KN, Santos JEP, Cerri RL et al (2007): Evaluation of methods of resynchronization for insemination in cows of unknown pregnancy status. J Anim Sci, 90, 4240-4252.

15. Jones AL, Lamb GC (2008): Nutrition, synchronization, and management of beef embryo transfer recipients. Theriogenology, 69, 107-115.

16. Leroy JLMR, de Kruif A (2006): Reduced reproductive performance in high producing dairy cows: Is there actually a problem?. Vlaams Diergen Tijds, 75, 55-60.

17. Lopez HI, Whittaker P, Behrouzi A et al (2018): Effect of initial GnRH and time of insemination on reproductive performance in cyclic and acyclic beef heifers subjected to a 5-d Cosynch plus progesterone protocol. Theriogenology, 106, 36-45.

18. Lucy MC, Billings HJ, Butler WR et al (2001): Efficacy of an intravaginal progesterone insert and an injection of $P F_{2}$ alpha for synchronizing estrus and shortening the interval to pregnancy in postpartum beef cows, peripubertal beef heifers, and dairy heifers. J Anim Sci, 79, 982-995.

19. Martinez MF, Kastelic JP, Adams GP et al (2000): Estrus synchronization and pregnancy rates in beef cattle given CIDR-B, prostaglandin and estradiol, or GnRH. Can Vet J, 41, 786-790.

20. Martinez MF, Kastelic JP, Adams GP et al (2002): The use of a progesterone-releasing device (CIDR-B) or melengestrol acetate with GnRH, LH, or estradiol benzoate for fixed-time AI in beef heifers. J Anim Sci, 80, 1746-1751.
21. Moreira F, de la Sota RL, Diaz T et al (2000): Effects of day of the estrous cycle at the initiation of a timed artificial insemination protocol on reproductive responses in dairy heifers. J Anim Sci, 78, 1568-1576.

22. Penny CD, Lowman BG, Scott NA et al (2000): Repeated oestrus synchronization of beef cows with progesterone implants and the effects of a gonadotrophin-releasing hormone against at implant insertion. Vet Rec, 146, 395398.

23. Prakash BS, Meyer HHD, Schallenberger E et al (1987): Development of sensitive Enzymeimmunoassay (EIA) for progesterone determination in unextracted bovine plasma using the second antibody technique. J Steroid Biochem, 28, 623-627.

24. Purcell SH, Beal WE, Gray KR (2005): Effect of a CIDR insert and flunixin meglumine, administered at the time of embryo transfer, on pregnancy rate and resynchronization of estrus in beef cattle. Theriogenology, 64, 867-878.

25. Rivera H, Lopez H, Fricke PM (2005): Use of intravaginal progesterone-releasing inserts in a synchronization protocol before timed AI and for synchronizing return to estrus in Holstein heifers. J Dairy Sci, 88, 957-968.

26. Silva E, Sterry RA, Kolb D et al (2007): Effect of interval to resynchronization of ovulation on fertility of lactating Holstein cows when using transrectal ultrasonography or a pregnancy-associated glycoprotein enzyme-linked immunosorbent assay to diagnose pregnancy status. J Dairy Sci, 92, 3643-3650.

27. Sterry RA, Welle ML, Fricke PM (2006): Effect of interval from timed artificial insemination to initiation of resynchronization of ovulation on fertility of lactating dairy cows. J Dairy Sci, 89, 2099-2109.

28. Stevenson JS, Kobayashi Y, Thompson KE (1999): Reproductive performance of dairy cows in various programmed breeding systems including ovsynch and combinations of gonadotropin-releasing hormone and prostaglandin $F_{2} \alpha$. J Dairy Sci, 82, 506-515.

29. Stevenson JS, Pursley JR, Garverick HA et al (2006): Treatment of cycling and noncycling lactating dairy cows with progesterone during ovsynch. J Dairy Sci, 89, 25672578.

30. Thatcher WW, Bilby TR, Bartolome JA, Silvestre F et al (2006): Strategies for improving fertility in the modern dairy cow. Theriogenology, 65, 30-44.

31. Van Eerdenburg FJCM (2006): Estrus detection in dairy cattle: How to beat the bull. Vlaams Diergen Tijds, 75, 6169.

32. Wiltbank MC, Sartori R, Herlihy MM et al (2011): Managing the dominant follicle in lactating dairy cows. Theriogenology, 76, 1568-1582.

33. Zuluaga JF, Williams GL (2007): High-pressure steam sterilization of previously used CIDR inserts enhances the magnitude of the acute increase in circulating progesterone after insertion in cows. Anim Reprod Sci, 107, 30-35. 